\title{
Financial Development, Entrepreneurship, and Job Satisfaction*
}

\author{
Milo Bianchi ${ }^{\dagger}$ \\ September 2010 \\ Forthcoming in The Review of Economics and Statistics
}

\begin{abstract}
This paper shows that utility differences between the self-employed and employees increase with financial development. This effect is not explained by increased profits but by an increased value of nonmonetary benefits, in particular job independence. We interpret these findings by building a simple occupational choice model in which financial constraints may impede the creation of firms and depress labor demand, thereby pushing some individuals into self-employment for lack of salaried jobs. In this setting, financial development favors a better matching between individual motivation and occupation, thereby increasing entrepreneurial utility despite increasing competition and so reducing profits.
\end{abstract}

Keywords: Financial development; entrepreneurship; job satisfaction.

JEL codes: L26, J20, O16.

\footnotetext{
* Sincere thanks to Abhijit Banerjee, Andrew Clark, Erik Lindqvist and Jörgen Weibull for very helpful discussions. I have also benefited from comments by two Referees, Cedric Argenton, Tore Ellingsen, Fabrice Etilé, Justina Fischer, Thibault Fally, Peter Haan, Andrew Oswald, Thomas Piketty, Asa Rosen, Giancarlo Spagnolo; and from several seminar presentations. Financial support from Région Ile-de-France and from the Fédération Bancaire Française Chair in Corporate Finance is gratefully acknowledged.

${ }^{\dagger}$ University Paris Dauphine. E-mail: milo.bianchi@dauphine.fr
} 


\section{Introduction}

From a standard economic viewpoint, the choice of becoming an entrepreneur displays some puzzling features. First, it is on average unprofitable: returns to capital are too low and risk too high (Hamilton, 2000; Moskowitz and Vissing-Jorgensen, 2002). Second, it seems to deliver high utility: entrepreneurs often report higher levels of job satisfaction than employees with similar characteristics (Blanchflower and Oswald, 1998; Hundley, 2001; Benz and Frey, 2004). A popular explanation of these puzzles posits that being an entrepreneur gives substantial non-monetary benefits and that, due to financial barriers to entry, entrepreneurs can enjoy utility above market clearing (Blanchflower and Oswald, 1998).

In this paper, we examine the above argument by exploring both theoretically and empirically how utility differences between entrepreneurs and employees respond to financial development. The aim is to contribute to a better understanding of occupational choices, as driven by these utility differences, particularly in relation to market conditions.

Analyzing utility differences is a way to highlight that individuals may become entrepreneurs for very different reasons. These latter may in turn significantly affect their market behaviors. For example, the type of entrepreneurs, particularly in terms of their motivations and aspirations, is a key predictor of their potential for job creation and growth. ${ }^{1}$ Similarly, whether entrepreneurs are driven by push or pull factors is a central determinant of their entry and exit over the business cycle. ${ }^{2}$ Hence, understanding entrepreneurs' motivations appears crucial for assessing their contribution to economic development and so ultimately for guiding policy interventions.

We start by building an occupational choice model in which individuals can choose between becoming an entrepreneur, which requires investing capital and hiring workers, or looking for a job as an employee. The model builds on two main ingredients. ${ }^{3}$ First, in addition to profits and wages, individuals value also non-monetary dimensions of their job. For example, entrepreneurs may derive utility from being their own boss. ${ }^{4}$ In line with the evidence in Fuchs-Schündeln (2009), we assume that individuals may differ in how much they like (or dislike) not having a boss, and so more generally in their (intrinsic) motivation for becoming an entrepreneur.

\footnotetext{
${ }^{1}$ See for example Wennekers and Thurik (1999), Reynolds, Bygrave, Autio, Cox and Hay (2002), Stel, Carree and Thurik (2005), van Praag and Versloot (2007).

${ }^{2}$ See for example Constant and Zimmermann (2004), Mandelman and Rojas (2007), Congregado, Golpe and Parker (2009).

${ }^{3}$ These are also our main points of departure from classic models of entrepreneurship. Seminal contributions in this literature include Knight (1921), Schumpeter (1934), Lucas (1978), Kihlstrom and Laffont (1979), Holmes and Schmitz (1990). See Parker (2004) and Bianchi and Henrekson (2005) for recent reviews.

${ }^{4}$ See for example Taylor (1996), Blanchflower and Oswald (1998), Hamilton (2000), Benz and Frey (2004).
} 
The second key ingredient is that labor demand is determined by the amount of individuals who become entrepreneurs. If entrepreneurs are a few, labor demand is low and so is the probability of finding a salaried job. This may push some individuals to become entrepreneurs through lack of better opportunities. ${ }^{5}$ It follows that individuals may start their businesses with very different motivations. On the one hand, they may choose to be entrepreneurs, as it is typically the case in more developed countries. On the other, they may become entrepreneurs by necessity. A substantial fraction of entrepreneurs in developing countries falls into this category (Reynolds et al., 2002), and these individuals may be very happy to leave their businesses for a salaried job. ${ }^{6}$

We then explore the effects of financial development in this setting. While the relation between financial constraints and occupational choices has received significant attention (see Banerjee and Duflo, 2005 and Levine, 2005 for recent surveys), we focus on the rather unexplored aspect of how financial development may affect individual utility, and in particular the non-monetary returns from entrepreneurship. As mentioned above, and as our analysis also confirms, such returns seem a crucial component of entrepreneurial choices.

In our model, financial development allows some poor individuals to access credit and set up a firm, which in turn increases competition and the demand for labor. In this way, the poor and most motivated individuals can become entrepreneurs, while the rich and least motivated individuals are induced to look for a salaried job. It follows that higher levels of financial development are associated with more satisfied entrepreneurs, and this is the case even if financial development increases competition and so reduces profits. In fact, in more financially developed countries, individuals tend to have chosen to be entrepreneurs because of their particular motivation rather than for lack of a better job.

These predictions are tested by using individual data on job satisfaction taken from the World Value Surveys, which provide comprehensive household surveys for a large set of countries over two decades. We focus on

\footnotetext{
${ }^{5}$ In most existing occupational choice models, on the contrary, entrepreneurs have chosen to be so and they could have become employees, while employees for some reason could not become entrepreneurs. However, if this were the case, entrepreneurs would always be better off than employees, which seems at odds with the evidence mentioned next and it will not be true in our data.

${ }^{6}$ See Banerjee and Duflo (2008) for a detailed account of this view in developing countries and Reynolds et al. (2002) for comprehensive surveys on necessity vs. opportunity entrepreneurs. Relatedly, see the literature on formality vs. informality (Harris and Todaro, 1970; Loayza, 1994; Schneider and Enste, 2000) and survival vs. growth enterprises (Berner, Gomez and Knorringa, 2008). On developed countries, see the literature on self-employment as a way out of unemployment (e.g. Evans and Leighton, 1989; Glocker and Steiner, 2007; Andersson and Wadensjö, 2007), and as a response to labor market discrimination (Borjas, 1986).
} 
self-reported levels of job satisfaction in order to account both for monetary and non-monetary returns from a job, which is crucial in our framework since profits and utility need not move in the same direction. Furthermore, in addition to standard demographic variables, these data provide information on beliefs, personality and different dimensions of individual jobs, which permits to test whether financial development works through these channels. Finally, while most of the evidence on entrepreneurs' job satisfaction comes from OECD countries, these data cover a wide sample of developing and developed countries. This allows us to draw a broader picture of whether entrepreneurship has different meanings, and financial development has different effects, according to a country's stage of development.

Our main findings lend support to the predictions of the model. First, descriptive statistics show that entrepreneurs report higher levels of job satisfaction than employees only in more financially developed countries; moreover, in these countries, entrepreneurs tend to report lower income than employees. These patterns are confirmed in a more structured analysis in which we control for a set of individual variables and, most importantly, for country-year fixed effects. It emerges that entrepreneurial utility relative to the utility of the employees increases with financial development. This result is robust to the inclusion of additional macroeconomic variables, accounting for example for better institutions or economic perspectives, as well as to the use of alternative measures of financial development. Moreover, this effect appears stronger in less financially developed countries, where many individuals become entrepreneurs by necessity and so many would be happy to switch to a salaried employment.

Finally, we explore the question of which mechanisms may underlie this relation. We first note that adding income to the explanatory variables does not change our results. Income appears (as expected) a strong determinant of job satisfaction, but higher financial development does not increase entrepreneurs' utility by making them richer. On the other hand, the effect of financial development becomes insignificant once we control for the degree of independence enjoyed in the job. This suggests that higher financial development allows entrepreneurs to enjoy higher non-monetary benefits, and in particular higher freedom in taking decisions in their job.

We present our model and theoretical analysis in Sections 2 and 3, respectively; Section 4 describes our data and Section 5 reports the empirical results; Section 6 concludes by discussing some policy implications. Omitted proofs and tables are reported in the Appendix.

\section{The Model}

Consider an economy populated by a unitary mass of risk-neutral individuals. Each individual is characterized by a type $(a, b)$, where $a$ describes 
his initial wealth and $b$ his taste for being an entrepreneur (which for now we simply call motivation). Wealth is drawn from a smooth cumulative distribution function $F$ with density $f$; motivation from a smooth cumulative distribution function $G$ with density $g$. These draws are assumed to be statistically independent. In addition, each individual is endowed with one unit of labor, which he may employ either for setting up a firm or to work as an employee. We now describe these options in further detail.

\subsection{Options}

First, an individual can set up a firm. We assume that each firm produces the same homogeneous good and it has the same size: it employs $k$ units of capital, $l$ workers, and it produces $q$ units of output. The profit is then

$$
\pi=p q-w l-r k
$$

where $p$ denotes the price of the good, $w$ denotes workers' wage, and $r$ is the market interest rate. In addition, managing a firm gives utility $b$. Hence, an individual who sets up a firm enjoys utility

$$
U_{1}=\pi+b .
$$

These individuals are called entrepreneurs, and we denote their population share with $x_{1}$. As a second option, an individual can look for a job in one of these firms. If he is hired, he enjoys utility

$$
U_{2}=w .
$$

The population share of workers is denoted with $x_{2}$. If he is not hired, he remains idle and enjoys some utility which we normalize to zero. ${ }^{7}$

\section{$2.2 \quad$ Markets}

There are three markets in our economy: a labor market, a product market and a credit market. In the labor market, the wage $w$ is bounded below by $\underline{w}$, which implies that this market may display excess supply. In this case, each applicant has the same probability of getting a job. While the general spirit of the model would be unchanged if we had market clearing wages, we wish to capture the idea that some persons may be pushed into self-employment as a way to avoiding unemployment. As detailed in the Introduction, this appears a prominent case, especially in developing countries. The specific

\footnotetext{
${ }^{7}$ Perhaps more sensibly, these individuals may be thought as turning to petty entrepreneurial activities, which require very little capital and no additional worker to operate and provide subsidence levels of production (see the references in footnote 6 ). This interpretation would reinforce our subsequent results.
} 
modelling choice is meant to be minimal with respect to this goal; more sophisticated reasons for non-market clearing wages are given for example in Weiss (1980) and Shapiro and Stiglitz (1984). The number of workers equals firms' demand, so we have

$$
x_{2}=l x_{1}
$$

The product market is described by a decreasing inverse demand function

$$
p=P(Q),
$$

where $Q=x_{1} q$ denotes the total output produced in the economy. The product demand is here taken as exogenous (say, coming from abroad). Again, this is meant to be the simplest way to model a situation in which a larger share of entrepreneurs increases competition in the product market. While one may also think of positive externalities among firms, we will show that, even disregarding them, entrepreneurs may report higher payoffs when more firms are created. ${ }^{8}$ Entrepreneurs take the price $p$ as given, and inelastically supply their output.

The financial market is competitive, the interest rate $r$ is fixed and exogenous, and we normalize it to one. An individual with wealth $a$ can ask for a loan $(k-a)$ in order to set up a firm. However, ex-post moral hazard limits the maximum size of this loan. Since, at $\operatorname{cost} c$, an individual can renege on his loan contract and run away with the money, the required repayment $(k-a)$ cannot exceed $c$. Hence, only individuals with enough wealth can set up a firm, and we define this lower bound on wealth as

$$
a^{*} \equiv k-c .
$$

The threshold $a^{*}$ decreases with $c$, which measures how easy it is to enforce loan contracts and is therefore an indicator of financial development. ${ }^{9}$

\subsection{Equilibrium}

In equilibrium, each individual, given his type, chooses an option in order to maximize his expected utility and the markets function according to equations (3), (4) and (5). In this equilibrium, an individual with wealth lower

\footnotetext{
${ }^{8}$ The same effect would occur if the product demand depended on wages, employment and on the amount of aggregate wealth not in invested firms (but not on entrepreneurial profit).

${ }^{9}$ Our formalization of financial market imperfections is very similar to the one in Banerjee and Newman (1993). The fact that only sufficiently wealthy individuals get loans can also be derived in a model of moral hazard à la Holmstrom and Tirole (1997) or costly screening. While we abstract from issues of optimal financing contract, we notice that condition (5) would be unchanged in the case of equity financing. The latter is however likely to play a minor role in our subsequent empirical analysis.
} 
than $a^{*}$ has no option other than to look for a job as worker. Instead, an individual with wealth greater than $a^{*}$ and motivation $b$ prefers to set up a firm if and only if

$$
p q-w l-r k+b \geq \frac{l x_{1}}{1-x_{1}} w,
$$

which implicitly defines a lower bound on $b$ as

$$
b^{*} \equiv \frac{w l}{1-x_{1}}+r k-p q .
$$

Provided that an equilibrium exists, the share of entrepreneurs $x_{1}$ is implicitly defined by

$$
x_{1}=\left[1-F\left(a^{*}\right)\right]\left[1-G\left(b^{*}\right)\right] .
$$

This equation also characterizes labor supply $\left(1-x_{1}\right)$ and, by equation (3), the share of workers $x_{2}=l x_{1}$. We are then interested in identifying the conditions for the existence and uniqueness of an equilibrium in our economy.

\section{Analysis}

To show that an equilibrium exists and that it is unique, we first note that the right hand side of equation (7) decreases in $b^{*}$. In fact, a higher $b^{*}$ leads to a lower share of entrepreneurs $x_{1}$ and so to a higher labor supply $\left(1-x_{1}\right)$ and to a higher price $p$ (since total output $Q$ increases in $x_{1}$ ). This implies that equation (7) uniquely defines $b^{*}$.

Moreover, the minimal motivation of those who prefer running a firm increases with the share of entrepreneurs $x_{1}$. In fact, a higher $x_{1}$ reduces the incentive to set up a firm both because it reduces the price $p$ and because it increases the demand for workers and so the probability of being hired. This is expressed in the next Lemma.

Lemma 1 The minimal entrepreneurial motivation $b^{*}$ is increasing with the share of entrepreneurs $x_{1}$.

It follows from Lemma 1 that the right hand side of equation (8) decreases in $x_{1}$, and thus equation (8) uniquely defines the share of entrepreneurs $x_{1}$. We summarize with the following Proposition.

Proposition 1 An equilibrium exists and it is unique. It is defined by equations (3), (5), (7) and (8).

\subsection{Financial Development, Profits and Job Satisfaction}

We are then interested in analyzing how financial development affects utility differences between entrepreneurs and workers. In particular, we consider 
how these effects may depend on a country's stage of development and how they may differ along monetary and non-monetary dimensions of individual utility. ${ }^{10}$ The average utility of an entrepreneur can be decomposed into the sum of profit

$$
\pi=p q-w l-r k
$$

and average non-monetary benefit

$$
\bar{b}=\frac{1}{1-G\left(b^{*}\right)} \int_{b \geq b^{*}} b g(b) d b .
$$

Utility differences are defined as

$$
D=\pi+\bar{b}-w .
$$

Differentiating equation (10) with respect to $c$, we write the effects of financial development on utility differences $D$ as

$$
\frac{\partial D}{\partial c}=\frac{\partial p}{\partial c} q-\frac{\partial w}{\partial c}(1+l)+\frac{\partial \bar{b}}{\partial c} .
$$

In order to interpret equation (11), we first note that, by relaxing wealth constraints, financial development allows a higher fraction of individuals to pay the cost of setting up a firm. The share of entrepreneurs then increases in financial development, up to the point at which everyone is employed either as a worker or as an entrepreneur, i.e. $x_{1}+l x_{1}=1$. We show this in the following Lemma.

Lemma 2 There exists a level of financial development $c^{*}$ such that the share of entrepreneurs $x_{1}$ increases in $c$ for $c<c^{*}$ and it is $x_{1}=1 /(1+l)$ for all $c \geq c^{*}$.

It follows that utility differences between entrepreneurs and workers tend to be higher in more financially developed countries. By equation (6) it must be that, for all those who become entrepreneurs,

$$
U_{1} \geq \frac{l x_{1}}{\left(1-x_{1}\right)} U_{2} .
$$

Given Lemma 1, the share of entrepreneurs is low when financial development is low. In this case, many individuals choose to be entrepreneurs even if they would prefer to be workers, since labor demand is low and so the probability of being hired is small. ${ }^{11}$

\footnotetext{
${ }^{10}$ Obviously, we are only considering the case in which $c<k$ and so financial development may have some effect.

${ }^{11}$ The fact that labor market imperfections are less likely to bind in more financially developed countries is due to our assumption that the minimum wage is not correlated to
} 
Hence, in countries with low financial development, entrepreneurship may come from the necessity of finding a job rather than from the choice of highly motivated individuals. In these countries, then, entrepreneurs need not be more satisfied with their job than employees. When financial development is high, instead, $x_{1}=1 /(1+l)$ and so $U_{1} \geq U_{2}$ for all those who become entrepreneurs. This implies that utility differences between entrepreneurs and workers are positive.

We then turn to the effect of financial development on profits and wages. For $c<c^{*}$, higher financial development increases labor demand, but the wage remains at its minimum $\underline{w}$ as there is still excess labor supply. Total production also increases (as less individuals end up idle), and this reduces the price $p$ and so the profit. For $c \geq c^{*}$, the share of entrepreneurs is constant, and so is the price, while the wage increases as more people compete to attract workers. This is shown more formally in the next Lemma.

Lemma 3 For $c<c^{*}$, the price $p$ decreases with $c$ and the wage $w$ is constant at $\underline{w}$; for $c \geq c^{*}$, the price $p$ is constant and the wage $w$ increases with $c$.

Lastly, we look at the effects of financial development on $\bar{b}$, which represents the non-monetary dimensions of individual utility. These effects depend on how the minimal motivation $b^{*}$ varies with $c$. For $c<c^{*}, b^{*}$ increases both as profits decrease (via product market competition) and as the probability of being hired increases. For $c \geq c^{*}, b^{*}$ still increases (though possibly less than for $c<c^{*}$ ) since labor market competition increases the wage. Hence, financial development allows poor individuals with high motivation to become entrepreneurs and induces those with low motivation to exit and look for jobs as employees. The following Proposition summarizes these predictions, which we test in the next Section.

\section{Proposition 2}

a. Entrepreneurs enjoy higher utility than employees only in more financially developed countries.

b. Entrepreneurial profits $\pi$ decrease with financial development.

c. Entrepreneurial non-monetary benefits $\bar{b}$ increase with financial development, and this effect may be stronger when financial development is low.

financial development. From a theoretical viewpoint, a positive relation between financial and labor market development is what one would expect in models where moral hazard on the part of workers is the reason for imperfect labor markets (see the references in Section 2.2) and moral hazard on the part of borrowers is the reason for imperfect access to credit. From an empirical viewpoint, this is a common theme in the literature on labor market imperfections and self-employment (see Addison and Teixeira, 2003 and the references in footnote 6 ), and it will be confirmed in our data too. 


\section{Testing the Model}

We are interested in exploring the effects of financial development on the utility of entrepreneurs relative to workers. In particular, in line with the interpretation suggested by the previous model, we look at the effects of financial development both on income and on non-monetary components of individual utility, and we test whether these effects depend on the country's stage of development.

It should already be noted, however, that we are going to estimate the changes in utility within the group of entrepreneurs relative to the group of workers, but the composition of these groups may change with financial development. In other words, we do not estimate the effects on the same individuals, but rather the effects on a representative individual within a group over time and across countries.

\subsection{Data}

In most of our analysis, the dependent variable is the self-reported level of job satisfaction. We consider a 1 to 10 index based on the answer to the question: "Overall, how satisfied or dissatisfied are you with your job?" This variable is taken from the World Value Surveys (WVS), and is available for 46 countries over the period $1981-2001 .^{12}$ We focus on job satisfaction since, as emphasized in the previous analysis, we need an indicator which includes both monetary and non-monetary returns from a job. Indeed, we will see that income is a major determinant of job satisfaction (which suggests we are not capturing purely non-monetary returns), but it is not the only determinant of job satisfaction (which suggests we are not capturing purely monetary returns either).

We are interested in exploring job satisfaction of the self-employed vs. employees. As common in survey studies, we classify an individual as selfemployed if he/she responded that self-employment represents his/her main activity, as opposed to salaried work. ${ }^{13}$ The self-employed represent both own-account entrepreneurs and employers, the vast majority being very small businesses. ${ }^{14}$ In relation to typical business statistics, which include only firms beyond some size, this allows a more direct link with occupational choices: even in highly financially developed countries, the vast majority of new firms are very small (Kerr and Nanda, 2009). Moreover, as argued in Blanchflower, Oswald and Stutzer (2001), self-employment is defined fairly consistently across countries.

\footnotetext{
${ }^{12}$ The surveys were conducted in four waves (in the early $80 \mathrm{~s}$, early $90 \mathrm{~s}$, late $90 \mathrm{~s}$, and early 2000s) and not all countries were included in all waves.

${ }^{13}$ One may also be classified as retired, unemployed, housewife, student, but for consistency with the model these individuals are not considered.

${ }^{14}$ Among non farmer self-employed in our sample, $5 \%$ have 10 or more employees, $35 \%$ have between 1 and 9 employees, and the rest are running a one-man business.
} 
For each individual, information is also provided on demographic characteristics, income, employment status, and several variables describing beliefs, personality and different dimensions of his or her job. In total, we have 50978 individual observations for full time employees and 7010 for the self-employed, divided into 88 country-year groups.

While financial development has a rather precise theoretical definition ${ }^{15}$, its measure presents several challenges (see Levine, 2005 for a discussion). In our analysis, we employ the most commonly used indicator in the literature on finance and growth: the level of domestic credit to the private sector, in percentage of GDP. The variable is taken from the World Development Indicators, published by the World Bank. In our sample, it displays a considerable variation both within and across countries, ranging from 1.68 (Poland, 1989) to 195.98 (Japan, 1990).

This indicator seems well suited for our purposes. It reflects the availability of bank credit, which is a fundamental ingredient to facilitate the access to credits for individuals or very small firms. On the other hand, private credits represent an outcome of financial development; hence, we will check the robustness of our analysis with an indicator of inputs of the financial system, i.e. privately owned banks. In particular, following Aghion, Fally and Scarpetta (2007), we employ a measure of the percentage of bank deposits held in privately owned banks.

Finally, we use other macroeconomic variables such as per capita GDP, GDP growth, unemployment, minimum wage, regulation, legal origin and trust. A more detailed description and summary statistics of all our variables can be found in the Appendix.

\section{Empirical Evidence}

\subsection{Descriptive Evidence}

As suggested by our model, the self-employed need not enjoy greater utility than the employees: in less financially developed countries, self-employment can simply be a way to avoid unemployment. To get a first idea of where the status of self-employed is a significant determinant of job satisfaction, we estimate the following equation separately for each country and year:

$$
U_{i}=\alpha+\beta X_{i}+\gamma S E_{i}+\varepsilon_{i} .
$$

The dependent variable $U_{i}$ denotes individual job satisfaction, $X_{i}$ is a set of individual variables including gender, age, age-squared, education, marital status, and $S E_{i}$ is a dummy equal to one if $i$ is self-employed. If the selfemployed enjoy higher utility in a given country and year, then the coefficient

\footnotetext{
${ }^{15}$ Roughly, the ease at which an individual with a profitable investment project can access the financial means necessary to fund such a project.
} 
$\gamma$ should be positive.

Table 2 reports the estimates of the coefficient $\gamma$ for each country and year. It is clear that the self-employed are not always more satisfied than the employees, but this tends to be the case only in more developed countries. Moreover, the results remain basically unchanged if income is included in the set of controls $X_{i}$ (columns 4-6). In fact, the set of countries and years in which the self-employed enjoy higher utility becomes slightly larger, which already suggests that income differentials are not the explanation behind differences in job satisfaction.

In order to better highlight these relationships, we construct the following variables. The variable $H A P P Y$ is equal to the estimated coefficient $\gamma$ in equation (13), weighted by the inverse of its standard error. We also run a similar regression with income as dependent variable in equation (13). Given this regression, we construct the dummy $R I C H$ which is again equal to the estimated coefficient $\gamma$ weighted by the inverse of its standard error. ${ }^{16}$

As shown in Table 3 , the variable $H A P P Y$ is positively correlated with financial development, GDP per capita and it is negatively correlated with $R I C H$, the level of unemployment (UNEMPL) and whether there is a mandatory minimum wage (MINWAGE). In accordance with our model, the self-employed enjoy higher utility than the employees in countries with high financial development and low labor market imperfections. Moreover, in these countries, the self-employed tend to have a lower income than the employees.

\subsection{Job Satisfaction and Financial Development}

The previous results suggest that utility differences are not due to financial market imperfections. We now explore this argument more systematically. We first estimate the equation

$$
U_{i, c, t}=\alpha+\beta X_{i, c, t}+\gamma I_{c, t}+\delta F D_{c, t} * S E_{i, c, t}+\varepsilon_{i, c, t},
$$

where $U_{i, c, t}$ denotes the reported job satisfaction for an individual $i$ in country $c$ and year $t ; X_{i, c, t}$ is a set of individual variables including gender, age, age-squared, education, marital status and employment status; $I_{c, t}$ is a country-year dummy, $F D_{c, t}$ is the level financial development and $S E_{i, c, t}$ is a dummy equal to one if $i$ is self-employed; finally, $\varepsilon_{i, c, t}$ is the error term. ${ }^{17}$

Equation (14) follows the spirit of Rajan and Zingales (1998), and it allows to estimate the effect of financial development on a particular set of individuals, the self-employed, after having controlled for the effect on the

\footnotetext{
${ }^{16}$ Our results are unchanged if instead we define $H A P P Y$ and $R I C H$ by considering only statistically significant coefficients.

${ }^{17}$ Since these errors may reflect common components within countries and employment status groups, we cluster standard errors at the country/employment status level.
} 
whole population and for country-year fixed effects. Our main interest is in the coefficient $\delta$, which describes how financial development affects the job satisfaction of the self-employed relative to (full-time) employees. ${ }^{18}$ When $\delta$ is positive, we say that financial development is positively correlated with entrepreneurial utility.

Table 4 reports our estimates on the full sample. The first column includes only the controls $X_{i, c, t}$. Self-employed, old, married and well-educated individuals tend to be more satisfied with their jobs. The second column describes our most basic specification, as reported in equation (14). The coefficient $\delta$ is positive and statistically significant. Financial development benefits the self-employed more than the employees.

In order to check the robustness of this result, we first try to identify whether financial development is capturing any effect of better macroeconomic conditions, like better institutions or economic perspectives, which may have a differential impact on the self-employed. When we include GDP per capita, interacted with the employment status dummy, the effect of financial development becomes slightly weaker, but still highly significant (column 3). Adding other macroeconomic variables like GDP growth (column 4), unemployment (column 5), and an index of regulatory pressure (column 6), always interacted with the self-employment dummy, does not change the estimate of $\delta$. Hence, our preferred specification, which serves as the baseline for the next analysis, is the one in column (3).

We then check whether this pattern is confirmed when using a variable based on the percentage of bank deposits held in privately owned banks (BANK), which is a measure of the development of the banking sector. This variable can be employed either as an instrument for financial development, as in Aghion et al. (2007) (see Table 5); or as an alternative measure of financial development (reduced form). The results in column 7 show that this measure of financial development is also positively correlated with entrepreneurial utility.

In addition, despite endogeneity may be less of a concern in our specifications, in that we estimate how a macro variable affects an individual variable and we include country-year fixed effects, we investigate whether our estimates may be biased, e.g. due to omitted variables, by using instrumental variables. In line with the previous literature, we instrument financial development with legal origin (as in several papers, surveyed in Levine, 2005), with the level of trust (as in Guiso, Sapienza and Zingales, 2004) and, as already mentioned, with the variable BANK. While these re-

\footnotetext{
${ }^{18}$ To facilitate the interpretation of our coefficients, part-time employees and farmers are excluded from the analysis. These exclusions do not change our results. For the same reason, in what follows, we report the estimates from OLS regressions. The results using ordered probit are qualitatively the same (see Ferrer-i Carbonell and Frijters, 2004 for a methodological discussion). Finally, these results are robust to the use of different sampling weights.
} 
sults should be interpreted with caution, due to well-known issues of finding valid instruments for financial development, we nonetheless notice that they are consistent with the previous estimates (see Table 5). ${ }^{19}$

Our next set of regressions estimates whether the effect of financial development depends on the country's stage of development. We divide the sample into country-years with high and with low financial development, where this threshold is determined by the median value in our sample. ${ }^{20}$ The results are in columns (1)-(2) of Table 6: the effects of financial development on entrepreneurial utility are positive and significant only in less developed countries.

Our model suggests a possible explanation for this result. In less developed countries, individuals become self-employed either because of their motivation or for lack of salaried jobs. As these countries develop their financial system, more jobs are created so only those who value it the most remain self-employed. This composition effect is weaker in more developed countries, where labor demand is higher and so most individuals become self-employed by choice. Indeed, we get similar findings if we split the sample according to unemployment (UNEMPL; columns 3-4) or to whether the country has a mandatory minimum wage (MINWAGE; columns 5-6). The effect of financial development on entrepreneurial utility is stronger in countries where unemployment is high and there is a minimum wage. ${ }^{21}$ Finally, to highlight the nonlinearity in the effects of financial development, column (7) includes the level of financial development squared and cube. The first appears to be negative, the second positive, and both are significant.

From these results, it is evident that the self-employed enjoy higher utility than the employees only in countries with high financial development; in less developed countries, entrepreneurial utility increases with financial development. In highly developed countries, approximately those above the sample median, the effect of financial development is U-shaped, and it appears not statistically significant if one applies a linear model.

\subsection{Mechanisms}

We now explore the mechanisms underlying the relation between financial development and entrepreneurial utility. As stressed in our model, these mechanisms should not be evaluated only in monetary terms.

We start by enriching the set of regressors in equation (14). First, we control for income, both in the full sample and separating country-years

\footnotetext{
${ }^{19}$ The only difference is that the effect of financial development does not appear statistically significant when instrumented by the variable LEGAL alone. This is probably due to the poor fit of this variable in the first stage, as shown by the F-statistic.

${ }^{20}$ Splitting the sample according to the mean gives the same qualitative results.

${ }^{21}$ Similarly, we find that the effects are stronger when GDP per capita is low and labor market regulation (as described by the variable LABOR) is high.
} 
according to their level of financial development. As shown in columns (1)(3) of Table 7, if anything, the results are even stronger. Income appears to be a major determinant of job satisfaction; but, as Benz and Frey (2004) have also observed, higher income does not explain entrepreneurial utility. In addition to the existing literature, we document that the effects of financial development on entrepreneurial utility are not only monetary. ${ }^{22}$

To get further evidence along these lines, we estimate equation (14) with income as dependent variable. Results appear in Table 8. We observe that the self-employed are richer than the employees in less developed countries, while this is not the case in more developed countries (columns 1-2). Moreover, financial development decreases the income of the self-employed, relative to the income of the employees (column 3), and this effect tends to be stronger in less developed countries (columns 4-5). The fact that financial development reduces profits is consistent with our model in that financial development increases competition, either in the product or in the labor market.

The results in columns (4)-(5) of Table 8 and those in columns (1)-(2) of Table 6 are used to draw Figure 1, which summarizes our main results so far. It clearly emerges that the effects of financial development on entrepreneurial utility may differ from those on profit; actually, in our case, these effects go exactly in the opposite direction. Entrepreneurial utility increases with financial development, while profit decreases. Moreover, both effects tend to be stronger in less developed countries.

The above results suggest that financial development works through nonmonetary aspects of job satisfaction. To better identify these mechanisms, we include in our regressions variables such as the degree of pride in one's work, the satisfaction with job security and the degree of independence enjoyed in the job. We also control for work-related beliefs such as how important work is in one's life, the main reason why one works, and so on. None of these variables significantly affects our results, with the exception of independence, which is an indicator derived from the question: "How free are you to make decisions in your job?" The importance of this variable in explaining entrepreneurial utility has already been pointed out in Benz and Frey (2004), and indeed, also in our sample, being self-employed becomes negatively related to job satisfaction when we add this control (Table 7, column 4).

We observe that, once independence has been controlled for, the effect of financial development almost halves in magnitude and is not statistically significant (column 5). Hence, our results add to the existing evidence by documenting that most of the effects of financial development seem to work

\footnotetext{
${ }^{22}$ Note that while income under-reporting may be more of an issue for the self-employed, this could only explain our results if under-reporting was higher in more financially developed countries.
} 


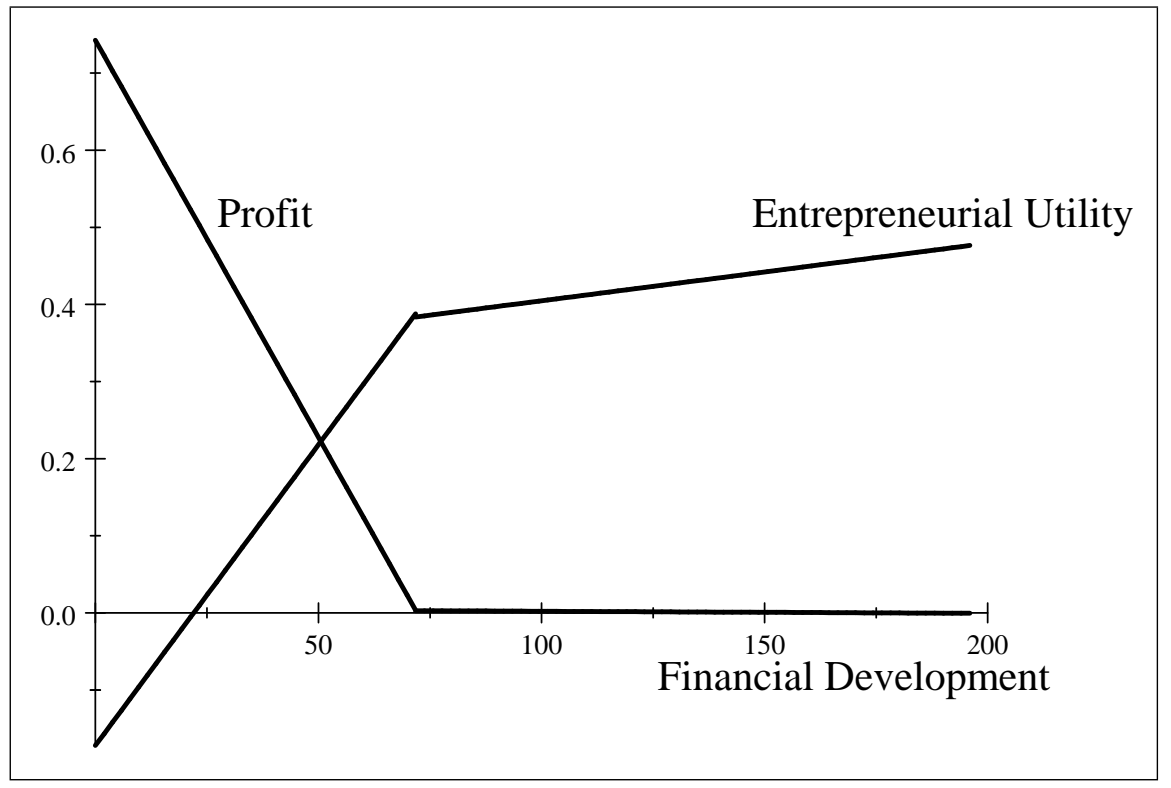

Figure 1: Entrepreneurial Profit, Utility and Financial Development. Estimates from Table 6, Columns (1)-(2) and Table 8, Columns (4)-(5).

through this channel. According to the model, this is the case because financial development offers to the most motivated individuals the opportunity to become entrepreneurs. Indeed, these results suggest that what we have so far called motivation may be (broadly) defined in terms of taste for independence at work. Moreover, the coefficient on independence in less developed countries is lower than in more developed countries (columns 5 and 6). ${ }^{23}$ This suggests that, as in our model, in more developed countries independence is given to those who value it the most.

\section{Conclusion and Policy Implications}

We started our analysis by examining the argument that entrepreneurs enjoy higher utility than employees due to a lack of financial development. This argument has not found support in our data; on the contrary, we have shown that financial development increases utility differences between the self-employed and employees. Moreover, this effect is not explained by increased profits; rather, it seems to work through non-monetary dimensions of job satisfaction, and in particular independence. We have interpreted these findings by building a simple occupational choice model in which financial development favors both job creation and a better matching between

\footnotetext{
${ }^{23}$ This difference is significant at the $5 \%$ level.
} 
individual motivation and occupation.

According to our results, the existence of utility differences is not due to some market imperfection, and as such it does not in itself call for policy intervention. By highlighting how financial development affects also nonmonetary dimensions of entrepreneurial utility, instead, the results point toward other policy implications. First, they bring an additional reason to promote an efficient financial system. Second, from the viewpoint of promoting entrepreneurship, they suggest that recognizing the importance of entrepreneurs' intrinsic motivation does not imply that external conditions do not matter. It then appears that a broader investigation on how different markets and institutions affect non-monetary returns from a job would be of great interest both for researchers and policy makers.

\section{References}

Addison, J. T. and Teixeira, P. (2003), 'The economics of employment protection', Journal of Labor Research 24(1), 85-129.

Aghion, P., Fally, T. and Scarpetta, S. (2007), 'Credit constraints as a barrier to the entry and post-entry growth of firms', Economic Policy 22(52), 731-779.

Andersson, P. and Wadensjö, E. (2007), 'Do the unemployed become successful entrepreneurs? a comparison between the unemployed, inactive and wage-earners', International Journal of Manpower 28, 604-626.

Banerjee, A. V. and Duflo, E. (2005), Growth theory through the lens of development economics, in P. Aghion and S. Durlauf, eds, 'Handbook of Economic Growth', Vol. 1 of Handbook of Economic Growth, Elsevier, chapter 7 , pp. $473-552$.

Banerjee, A. V. and Duflo, E. (2008), 'What is middle class about the middle classes around the world?', Journal of Economic Perspectives 22(2), 328.

Banerjee, A. V. and Newman, A. F. (1993), 'Occupational choice and the process of development', Journal of Political Economy 101(2), 274-98.

Benz, M. and Frey, B. S. (2004), 'Being independent raises happiness at work', Swedish Economic Policy Review 11, 95-134.

Berner, E., Gomez, G. and Knorringa, P. (2008), 'Helping a Large Number of People Become a Little Less Poor: The Logic of Survival Entrepreneurs', Mimeo. ISS, The Hague. 
Bianchi, M. and Henrekson, M. (2005), 'Is neoclassical economics still entrepreneurless?', Kyklos 58(3), 353-377.

Blanchflower, D. G. and Oswald, A. J. (1998), 'What makes an entrepreneur?', Journal of Labor Economics 16(1), 26-60.

Blanchflower, D. G., Oswald, A. and Stutzer, A. (2001), 'Latent entrepreneurship across nations', European Economic Review 45(4-6), 680-691.

Borjas, G. J. (1986), 'The self-employment experience of immigrants', Journal of Human Resources 21(4), 485-506.

Botero, J., Djankov, S., La Porta, R. and Lopez-De-Silanes, F. C. (2004), 'The regulation of labor', Quarterly Journal of Economics $\mathbf{1 1 9}(4), 1339-1382$.

Congregado, E., Golpe, A. A. and Parker, S. C. (2009), 'The dynamics of entrepreneurship: Hysteresis, business cycles and government policy', IZA Discussion Paper No. 4093.

Constant, A. and Zimmermann, K. F. (2004), 'Self-employment dynamics across the business cycle: Migrants versus natives', IZA Discussion Paper No. 1386.

Evans, D. S. and Leighton, L. S. (1989), 'Some empirical aspects of entrepreneurship', American Economic Review 79(3), 519-35.

Ferrer-i Carbonell, A. and Frijters, P. (2004), 'How important is methodology for the estimates of the determinants of happiness?', Economic Journal 114(497), 641-659.

Fuchs-Schündeln, N. (2009), 'On preferences for being self-employed', Journal of Economic Behavior and Organization 71(2), 162-171.

Glocker, D. and Steiner, V. (2007), 'Self-employment: A way to end unemployment? empirical evidence from german pseudo-panel data', IZA Discussion Paper No. 2561.

Guiso, L., Sapienza, P. and Zingales, L. (2004), 'Does Local Financial Development Matter?', Quarterly Journal of Economics 119(3), 929-969.

Hamilton, B. H. (2000), 'Does entrepreneurship pay? an empirical analysis of the returns to self-employment', Journal of Political Economy 108(3), 604-631.

Harris, J. R. and Todaro, M. P. (1970), 'Migration, unemployment \& development: A two-sector analysis', American Economic Review 60(1), 126-42. 
Holmes, T. J. and Schmitz, James A, J. (1990), 'A theory of entrepreneurship and its application to the study of business transfers', Journal of Political Economy 98(2), 265-94.

Holmstrom, B. and Tirole, J. (1997), 'Financial intermediation, loanable funds, and the real sector', Quarterly Journal of Economics $\mathbf{1 1 2}(3), 663-91$.

Hundley, G. (2001), 'Why and when are the self-employed more satisfied with their work?', Industrial Relations 40(2), 293-316.

Kerr, W. R. and Nanda, R. (2009), 'Financing constraints and entrepreneurship', NBER Working Paper No. 15498.

Kihlstrom, R. E. and Laffont, J.-J. (1979), 'A general equilibrium entrepreneurial theory of firm formation based on risk aversion', Journal of Political Economy 87(4), 719-48.

Knight, F. (1921), Risk, Uncertainty and Profit, New York: Houghton Mifflin.

La Porta, R., Lopez-de Silanes, F., Shleifer, A. and Vishny, R. (1998), 'Law and Finance', Journal of Political Economy 106(6), 1113-1155.

Levine, R. (2005), Finance and growth: Theory and evidence, in P. Aghion and S. Durlauf, eds, 'Handbook of Economic Growth', Vol. 1 of Handbook of Economic Growth, Elsevier, chapter 12, pp. 865-934.

Loayza, N. V. (1994), 'Labor regulations and the informal economy', The World Bank Policy Research Working Paper No. 1335.

Lucas, R. E. J. (1978), 'On the size distribution of business firms', Bell Journal of Economics 9(2), 508-523.

Mandelman, F. S. and Rojas, G. V. M. (2007), 'Microentrepreneurship and the business cycle: is self-employment a desired outcome?', Federal Reserve Bank of Atlanta Working Paper No. 2007-15.

Moskowitz, T. J. and Vissing-Jorgensen, A. (2002), 'The returns to entrepreneurial investment: A private equity premium puzzle?', American Economic Review 92(4), 745-778.

Parker, S. (2004), The Economics of Self-Employment and Entrepreneurship, Cambridge University Press.

Rajan, R. G. and Zingales, L. (1998), 'Financial dependence and growth', American Economic Review 88(3), 559-86. 
Reynolds, P., Bygrave, W., Autio, E., Cox, L. and Hay, M. (2002), Global Entrepreneurship Monitor: 2002 executive report, Babson College.

Schneider, F. and Enste, D. H. (2000), 'Shadow economies: Size, causes, and consequences', Journal of Economic Literature 38(1), 77-114.

Schumpeter, J. A. (1934), The Theory of Economic Development, Cambridge, MA: Harvard University Press.

Shapiro, C. and Stiglitz, J. E. (1984), 'Equilibrium unemployment as a worker discipline device', American Economic Review 74(3), 433-44.

Stel, A., Carree, M. and Thurik, R. (2005), 'The Effect of Entrepreneurial Activity on National Economic Growth', Small Business Economics 24(3), 311-321.

Taylor, M. P. (1996), 'Earnings, independence or unemployment: Why become self-employed?', Oxford Bulletin of Economics and Statistics $\mathbf{5 8}(2), 253-66$.

van Praag, C. M. and Versloot, P. H. (2007), 'What is the value of entrepreneurship? a review of recent research', IZA Discussion Paper No. 3014 .

Weiss, A. W. (1980), 'Job queues and layoffs in labor markets with flexible wages', Journal of Political Economy 88(3), 526-38.

Wennekers, S. and Thurik, R. (1999), 'Linking Entrepreneurship and Economic Growth', Small Business Economics 13(1), 27-56. 


\section{Appendix}

\subsection{Omitted Proofs}

Lemma 1 The minimal entrepreneurial motivation $b^{*}$ is increasing with the share of entrepreneurs $x_{1}$.

Proof. With simple algebra, differentiating equation (7), one can write

$$
\frac{\partial b^{*}}{\partial x_{1}}=\frac{w l}{\left(1-x_{1}\right)^{2}}-\frac{\partial p}{\partial x_{1}} q .
$$

This expression is positive since the first term is positive (note that $x_{1}$ may increase only if $l x_{1}+x_{1}<1$, i.e. there is excess labor supply and $w=\underline{w}$, which implies that $w$ does not depend directly on $x_{1}$ ) and the second term is negative ( $Q$ increases in $x_{1}$ and so $p$ decreases in $\left.x_{1}\right)$.

Lemma 2 There exists a level of financial development $c^{*}$ such that the share of entrepreneurs $x_{1}$ increases in $c$ for $c<c^{*}$ and it is $x_{1}=1 /(1+l)$ for all $c \geq c^{*}$.

Proof. Suppose first that $l x_{1}+x_{1}<1$, i.e. there is excess labor supply and $w=\underline{w}$. Implicitly differentiating equation (8), we have

$$
\frac{\partial x_{1}}{\partial c}=\frac{f\left(a^{*}\right)\left[1-G\left(b^{*}\right)\right]}{1+\left[1-F\left(a^{*}\right)\right] g\left(b^{*}\right) \frac{\partial b^{*}}{\partial x_{1}}} .
$$

The numerator measures the increment in individuals who can afford to become entrepreneurs. The denominator indicates how the mass of individuals who are sufficiently motivated and so willing to be entrepreneurs changes as entry increases. Given Lemma $1, \partial b^{*} / \partial x_{1}$ is positive and hence $\partial x_{1} / \partial c$ is also positive. Hence, $x_{1}$ is strictly increasing in $c$ for $l x_{1}+x_{1}<1$. Let $c^{*}$ be the minimal $c$ such that $x_{1}=1 /(1+l)$. Beyond $c^{*}, x_{1}$ cannot increase any further since everyone is employed either as a worker or as an entrepreneur.

Lemma 3 For $c<c^{*}$, the price $p$ decreases with $c$ and the wage $w$ is constant at $\underline{w}$; for $c \geq c^{*}$, the price $p$ is constant and the wage $w$ increases with $c$.

Proof. Given Lemma 2, $x_{1}$ is strictly increasing in $c$ for $c<c^{*}$. The total output produced $Q=x_{1} q$ depends positively on $x_{1}$ hence for equation (4) the price $p$ decreases with $x_{1}$. The wage $w$ instead does not depend on $x_{1}$, since $x_{1}$ can increase only if there is excess labor supply and so $w=\underline{w}$. For $c \geq c^{*}, x_{1}$ is fixed and so $p$ is fixed; $w$ instead is such that demand equals 
supply of labor, i.e. $L=1-x_{1}-l x_{1} \equiv 0$. Implicitly differentiating $L$, we have

$$
\frac{\partial w}{\partial c}=-\frac{\partial L}{\partial c} / \frac{\partial L}{\partial w}=\frac{f\left(a^{*}\right)\left[1-G\left(b^{*}\right)\right]}{\left[1-F\left(a^{*}\right)\right] g\left(b^{*}\right)(1+l)}>0 .
$$

\section{Proposition 2}

a. Entrepreneurs enjoy higher utility than employees only in more financially developed countries.

b. Entrepreneurial profits $\pi$ decrease with financial development.

c. Entrepreneurial non-monetary benefits $\bar{b}$ increase with financial development, and this effect may be stronger when financial development is low.

Proof. Recall from equation (12) that

$$
U_{1} \geq \frac{l x_{1}}{1-x_{1}} U_{2}
$$

If $c$ is low, then $x_{1}$ is low and so there are many entrepreneurs for which $U_{1}<U_{2}$. These are the individuals with motivation $b \in\left[b^{*}, b^{* *}\right]$, where $b^{* *}$ is such that $\pi+b^{* *}=w$. If $c \geq c^{*}$, then $l x_{1}=1-x_{1}$ and $U_{1} \geq U_{2}$ for all entrepreneurs. Part $b$. of the Proposition follows from Lemma 3: as $c$ increases, either $p$ decreases or $w$ increases, hence the profit $\pi=p q-w l-k$ decreases with $c$. Finally, from equation (9), we have

$$
\frac{\partial \bar{b}}{\partial c}=\frac{g\left(b^{*}\right)}{1-G\left(b^{*}\right)}\left(\bar{b}-b^{*}\right) \frac{\partial b^{*}}{\partial c} .
$$

From equation (7), we see that $b^{*}$ increases in $x_{1}$ and $p$ and it decreases in $w$ so, given Lemmas 1,2 and $3, \partial b^{*} / \partial c>0$. This implies that $\bar{b}$ increases in $c$. Notice also that this effect may be stronger for $c<c^{*}$, when $b^{*}$ increases in $c$ both as the result of reduced profit and of an higher probability of being hired (an higher $l x_{1} /\left(1-x_{1}\right)$ ). For $c \geq c^{*}$, instead, only the first effect is at play. 


\subsection{Description of variables}

\section{Individual variables:}

Job Satisfaction: 1-10 index based on the answer to "Overall, how satisfied or dissatisfied are you with your job?" 10 indicates "satisfied", 1 indicates "dissatisfied". Source: WVS, variable c033.

SE: Dummy equal 1 if the individual is self-employed. Source: WVS, variable $\mathrm{x} 028$.

Female: Dummy equal 1 if the individual is a female. Source: WVS, variable $\mathrm{x} 001$.

Age: Age of the individual. Source: WVS, variable x003.

Married: Dummy equal 1 if the individual is married or living together as married. Source: WVS, variable x007.

Education: 1-10 index for the age at which the individual completed education. 1 indicates the individual was less than 13 years old, 10 indicates the individual was more than 20 years old. Source: WVS, variable x023r.

Income: 1-11 index of the individual income scale. Source: WVS, variable x047.

Independence in job: 1-10 index based on the answer to "How free are you to make decisions in your job?" 10 indicates "a great deal", 1 indicates "none at all". Source: WVS, variable c034.

\section{Macro variables:}

FD: Financial Development, measured by the level of domestic credit to the private sector (\% of GDP). Source: World Development Indicators. (available at www.worldbank.org/data)

GDP: GDP per capita (at constant 2000 US\$). Source: World Development Indicators. (available at www.worldbank.org/data)

UNEMPL: Total unemployment (\% of total labor force). Source: World Development Indicators. (available at www.worldbank.org/data)

MINWAGE: Dummy equal 1 if the country has a mandatory minimum wage defined by statute or there is a minimum wage established by mandatory collective agreement which is legally binding for most sectors of the 
economy. The variable is a cross county taken in 1997. Source: Botero, Djankov, La Porta and Lopez-De-Silanes (2004).

LABOR: 0-10 variable rating the regulation of labor markets. 0 corresponds to stronger state intervention. Source: Economic Freedom of the World: 2007 Annual Report. (available at www.freetheworld.com)

REGULAT: 0-10 variable rating the regulation of credit markets, labor markets and businesses. 0 corresponds to stronger state intervention. Source: Economic Freedom of the World: 2007 Annual Report. (available at www.freetheworld.com)

GROWTH: GDP per capita growth (annual \%). Source: World Development Indicators. (available at www.worldbank.org/data)

BANK: 0-10 variable based on the percentage of bank deposits held in privately owned banks. Countries with larger shares of privately held deposits received higher ratings. Source: Economic Freedom of the World: 2007 Annual Report. (available at www.freetheworld.com)

TRUST: Average response to the question "Generally speaking, would you say that most people can be trusted?" 1 indicates that "most people can be trusted", 0 indicates "Can't be too careful in dealing with people". Source: WVS, variable a165.

LEGAL: Dummy equal 1 if the country's legal origin is civil law. Source: La Porta, Lopez-de Silanes, Shleifer and Vishny (1998). 


\subsection{Tables}

Table 1: Summary statistics

\begin{tabular}{lccccc}
\hline Variable & Obs & Mean & Std. Dev & Min & Max \\
\hline \hline & & & & & \\
Job Satisfaction & 67348 & 7.297039 & 2.182215 & 1 & 10 \\
Self-Empl. (SE) & 65999 & .1062137 & .3081133 & 0 & 1 \\
Female & 67288 & .4372399 & .4960492 & 0 & 1 \\
Age & 67193 & 38.48615 & 12.25545 & 16 & 100 \\
Married & 67100 & .6798361 & .4665429 & 0 & 1 \\
Education & 60816 & 6.730318 & 2.719934 & 1 & 10 \\
Income & 57479 & 5.53122 & 2.410663 & 1 & 11 \\
Independence & 66691 & 6.571516 & 2.68442 & 1 & 10 \\
FD & 62248 & 66.83599 & 38.53845 & 1.68 & 195.98 \\
GDP & 65197 & 13311.15 & 9797.721 & 317 & 43267 \\
UNEMPL & 43829 & 8.398348 & 4.252513 & .6 & 16.4 \\
MINWAGE & 60068 & .65589 & .4750811 & 0 & 1 \\
LABOR & 54640 & 4.654596 & 1.43885 & 1.8 & 7.7 \\
REGULAT & 62491 & 5.326551 & 1.204252 & 2.5 & 8.3 \\
GROWTH & 64627 & 1.231817 & 4.798632 & -14.57 & 12.67 \\
BANK & 62021 & 5.678464 & 3.725851 & 0 & 10 \\
TRUST & 67348 & .3476848 & .1347544 & .0645527 & .6646154 \\
LEGAL & 43981 & .727928 & .4450318 & 0 & 1 \\
\hline \hline
\end{tabular}

NotE: The table reports summary statistics for all variables used in the regressions. A definition of these variables can be found in Section 7.2. 
Table 2: Job Satisfaction across countries

\begin{tabular}{|c|c|c|c|c|c|c|c|}
\hline \multirow[b]{3}{*}{ Country } & \multirow[b]{3}{*}{ Year } & \multicolumn{3}{|c|}{ Income not included as control } & \multicolumn{3}{|c|}{ Income included as control } \\
\hline & & & $(2)$ & (3) & $(4)$ & $(5)$ & (6) \\
\hline & & Self-Empl & Std Error & Obs & Self-Empl & Std Error & Obs \\
\hline Argentina & 1991 & 0,218 & 0,118 & 356 & 0,270 & 0,140 & 276 \\
\hline Austria & 1990 & 0,021 & 0,112 & 689 & 0,049 & 0,116 & 663 \\
\hline Austria & 1999 & 0,139 & 0,117 & 762 & 0,182 & 0,144 & 623 \\
\hline Belarus & 2000 & $-0,232$ & 0,204 & 636 & $-0,451$ & 0,208 & 630 \\
\hline Belgium & 1981 & 0,189 & 0,159 & 503 & 0,104 & 0,185 & 429 \\
\hline Belgium & 1990 & 0,145 & 0,080 & 1282 & 0,099 & 0,107 & 825 \\
\hline Belgium & 1999 & 0,183 & 0,129 & 836 & 0,318 & 0,146 & 711 \\
\hline Brazil & 1991 & 0,073 & 0,097 & 797 & 0,092 & 0,100 & 764 \\
\hline Bulgaria & 1990 & 0,080 & 0,186 & 414 & $-0,019$ & 0,256 & 650 \\
\hline Bulgaria & 1999 & 0,078 & 0,244 & 693 & $-0,024$ & 0,199 & 397 \\
\hline Canada & 1982 & 0,537 & 0,249 & 657 & 0,669 & 0,277 & 573 \\
\hline Canada & 1990 & 0,363 & 0,129 & 1004 & 0,482 & 0,143 & 876 \\
\hline Chile & 1990 & $-0,025$ & 0,109 & 520 & 0,012 & 0,110 & 518 \\
\hline China & 1990 & $-0,001$ & 0,097 & 567 & $-0,024$ & 0,098 & 560 \\
\hline Croatia & 1999 & $-0,249$ & 0,180 & 474 & $-0,362$ & 0,193 & 459 \\
\hline Czech Republic & 1990 & 0,192 & 0,269 & 610 & 0,158 & 0,270 & 607 \\
\hline Czech Republic & 1991 & 0,287 & 0,142 & 1371 & 0,296 & 0,148 & 1322 \\
\hline Czech Republic & 1999 & 0,409 & 0,114 & 981 & 0,379 & 0,121 & 891 \\
\hline Denmark & 1981 & 0,338 & 0,168 & 674 & 0,299 & 0,179 & 622 \\
\hline Denmark & 1990 & 0,280 & 0,140 & 639 & 0,564 & 0,180 & 571 \\
\hline Denmark & 1999 & 0,914 & 0,207 & 627 & 0,768 & 0,218 & 578 \\
\hline Estonia & 1990 & 0,073 & 0,296 & 768 & 0,061 & 0,297 & 767 \\
\hline Estonia & 1999 & 0,293 & 0,167 & 575 & 0,313 & 0,218 & 494 \\
\hline Finland & 1990 & 0,197 & 0,151 & 424 & $-0,022$ & 0,031 & 424 \\
\hline Finland & 2000 & 0,163 & 0,148 & 490 & 0,222 & 0,153 & 449 \\
\hline France & 1981 & 0,500 & 0,149 & 588 & 0,712 & 0,198 & 465 \\
\hline France & 1990 & 0,228 & 0,237 & 453 & 0,176 & 0,338 & 389 \\
\hline France & 1999 & 0,224 & 0,227 & 736 & 0,166 & 0,278 & 610 \\
\hline Germany & 1990 & 0,476 & 0,119 & 2124 & 0,479 & 0,125 & 2045 \\
\hline Germany & 1999 & 0,055 & 0,117 & 862 & 0,106 & 0,173 & 607 \\
\hline Greece & 1999 & 0,136 & 0,122 & 644 & 0,046 & 0,134 & 563 \\
\hline Hungary & 1991 & 0,063 & 0,283 & 552 & 0,059 & 0,283 & 544 \\
\hline Hungary & 1999 & 0,012 & 0,287 & 420 & $-0,118$ & 0,301 & 409 \\
\hline Iceland & 1984 & 0,168 & 0,107 & 679 & 0,175 & 0,112 & 642 \\
\hline Iceland & 1990 & 0,201 & 0,107 & 559 & 0,046 & 0,022 & 434 \\
\hline Iceland & 1999 & 0,273 & 0,100 & 732 & 0,294 & 0,105 & 695 \\
\hline India & 1990 & 0,064 & 0,096 & 580 & 0,004 & 0,097 & 573 \\
\hline Ireland & 1981 & 0,198 & 0,139 & 598 & 0,027 & 0,269 & 222 \\
\hline Ireland & 1990 & 0,078 & 0,135 & 549 & 0,162 & 0,148 & 486 \\
\hline Ireland & 1999 & 0,086 & 0,127 & 519 & 0,124 & 0,138 & 461 \\
\hline Italy & 1981 & 0,522 & 0,092 & 699 & 0,464 & 0,108 & 541 \\
\hline Italy & 1990 & 0,292 & 0,092 & 1030 & 0,268 & 0,114 & 782 \\
\hline Italy & 1999 & 0,092 & 0,082 & 1031 & 0,102 & 0,093 & 795 \\
\hline Japan & 1990 & 0,322 & 0,127 & 469 & 0,237 & 0,133 & 429 \\
\hline
\end{tabular}


Table 2 continued

\begin{tabular}{|c|c|c|c|c|c|c|c|}
\hline \multirow[b]{3}{*}{ Country } & \multirow[b]{3}{*}{ Year } & \multicolumn{3}{|c|}{ Income not included as control } & \multicolumn{3}{|c|}{ Income included as control } \\
\hline & & & $(2)$ & (3) & (4) & $(5)$ & (6) \\
\hline & & Self-Empl & Std Error & Obs & Self-Empl & Std Error & Obs \\
\hline Latvia & 1990 & 0,099 & 0,224 & 697 & 0,113 & 0,224 & 685 \\
\hline Latvia & 1999 & $-0,327$ & 0,298 & 455 & $-0,462$ & 0,316 & 430 \\
\hline Lithuania & 1990 & 0,552 & 0,265 & 677 & 0,588 & 0,285 & 650 \\
\hline Lithuania & 1999 & $-0,583$ & 0,244 & 513 & $-0,663$ & 0,291 & 447 \\
\hline Luxembourg & 1999 & 0,363 & 0,220 & 589 & 0,469 & 0,285 & 342 \\
\hline Malta & 1983 & 0,520 & 0,301 & 205 & 1,023 & 0,471 & 147 \\
\hline Malta & 1999 & $-0,029$ & 0,182 & 464 & $-0,145$ & 0,206 & 352 \\
\hline Mexico & 1990 & $-0,170$ & 0,106 & 563 & $-0,172$ & 0,107 & 541 \\
\hline Netherlands & 1981 & 0,267 & 0,211 & 480 & 0,089 & 0,261 & 350 \\
\hline Netherlands & 1990 & 0,445 & 0,305 & 432 & 0,389 & 0,334 & 358 \\
\hline Netherlands & 1999 & 0,489 & 0,130 & 631 & 0,495 & 0,138 & 597 \\
\hline Nigeria & 1990 & 0,063 & 0,149 & 226 & $-0,029$ & 0,156 & 203 \\
\hline North Ireland & 1981 & 0,670 & 0,371 & 165 & $-0,300$ & 0,163 & 36 \\
\hline North Ireland & 1990 & 1,242 & 0,495 & 156 & 0,945 & 0,674 & 122 \\
\hline North Ireland & 1999 & 0,130 & 0,141 & 464 & 0,142 & 0,173 & 340 \\
\hline Norway & 1982 & 0,263 & 0,119 & 713 & 0,300 & 0,127 & 684 \\
\hline Norway & 1990 & 0,215 & 0,108 & 845 & 0,314 & 0,118 & 741 \\
\hline Poland & 1989 & $-0,173$ & 0,122 & 477 & $-0,232$ & 0,123 & 474 \\
\hline Poland & 1990 & $-0,075$ & 0,116 & 567 & $-0,144$ & 0,120 & 548 \\
\hline Poland & 1999 & $-0,463$ & 0,143 & 506 & $-0,475$ & 0,144 & 495 \\
\hline Portugal & 1990 & 0,224 & 0,129 & 611 & 0,188 & 0,132 & 585 \\
\hline Portugal & 1999 & 0,237 & 0,141 & 442 & NA & NA & NA \\
\hline Romania & 1993 & 0,055 & 0,179 & 551 & $-0,019$ & 0,179 & 551 \\
\hline Romania & 1999 & 0,296 & 0,227 & 416 & 0,285 & 0,238 & 388 \\
\hline Russia & 1999 & 0,113 & 0,164 & 1310 & 0,091 & 0,176 & 1235 \\
\hline Slovakia & 1990 & 0,109 & 0,515 & 321 & 0,067 & 0,516 & 320 \\
\hline Slovakia & 1991 & 0,267 & 0,224 & 708 & 0,166 & 0,234 & 672 \\
\hline Slovakia & 1999 & 0,244 & 0,165 & 754 & $-0,021$ & 0,182 & 707 \\
\hline Slovenia & 1992 & 0,270 & 0,202 & 567 & 0,192 & 0,204 & 561 \\
\hline Slovenia & 1999 & $-0,085$ & 0,208 & 527 & 0,080 & 0,332 & 366 \\
\hline South Africa & 1990 & 0,192 & 0,099 & 1056 & 0,206 & 0,104 & 927 \\
\hline Spain & 1981 & 0,277 & 0,074 & 984 & 0,271 & 0,077 & 897 \\
\hline Spain & 1990 & 0,293 & 0,067 & 1624 & 0,276 & 0,074 & 1375 \\
\hline Spain & 1999 & 0,299 & 0,131 & 478 & 0,092 & 0,175 & 319 \\
\hline Sweden & 1982 & 0,327 & 0,150 & 651 & 0,338 & 0,160 & 619 \\
\hline Sweden & 1990 & 0,408 & 0,133 & 770 & NA & NA & NA \\
\hline Sweden & 1999 & 0,709 & 0,233 & 634 & 0,626 & 0,240 & 621 \\
\hline Turkey & 2001 & $-0,078$ & 0,118 & 369 & $-0,058$ & 0,119 & 369 \\
\hline UK & 1981 & 0,737 & 0,224 & 678 & 0,590 & 0,262 & 509 \\
\hline UK & 1990 & 0,592 & 0,129 & 838 & 0,593 & 0,153 & 657 \\
\hline UK & 1999 & 0,312 & 0,210 & 434 & 0,146 & 0,244 & 318 \\
\hline Ukraine & 1999 & $-0,097$ & 0,330 & 585 & $-0,129$ & 0,332 & 571 \\
\hline US & 1982 & 0,506 & 0,230 & 1317 & 0,577 & 0,238 & 1262 \\
\hline US & 1990 & 0,359 & 0,161 & 1082 & 0,321 & 0,168 & 1016 \\
\hline
\end{tabular}

NoTE: This table reports the results of ordered probit regressions of job satisfaction on a dummy equal 1 if the individual is self-employed. Columns (1) and (4) report the estimated coefficients. In columns (1)-(3), the controls are gender, age, age squared, education, marital status. In columns (4)-(6), income is also included in the controls. NA indicates that no observation on income is available for that country in that year. Coefficients significant at the $5 \%$ level a2Q reported in bold. 
Table 3: Partial correlations

\begin{tabular}{lcccccc}
\hline & HAPPY & RICH & FD & GDP & UNEMPL & MINWAGE \\
\hline \hline HAPPY & 1 & & & & & \\
RICH & $-0.0308^{*}$ & 1 & & & & \\
FD & $0.4636^{*}$ & $-0.2458^{*}$ & 1 & & & \\
GDP & $0.4413^{*}$ & $-0.1609^{*}$ & $0.6739^{*}$ & 1 & & \\
UNEMPL & $-0.0764^{*}$ & $0.2652^{*}$ & $-0.3636^{*}$ & $-0.4719^{*}$ & 1 & \\
MINWAGE & $-0.3213^{*}$ & $-0.0160^{*}$ & $-0.3117^{*}$ & $-0.5300^{*}$ & $0.3291^{*}$ & 1 \\
\hline
\end{tabular}

Note: The table reports partial correlation coefficients. The star indicates significance at the $1 \%$ level. HAPPY is equal to the estimated coefficient on selfemployment, weighted by the inverse of its standard error, in an ordered probit regression with job satisfaction as dependent variable. RICH is equal to the estimated coefficient on self-employment, weighted by the inverse of its standard error, in an ordered probit regression with income as dependent variable. All regressions include gender, age, age squared, education, marital status as controls. 
Table 4: Financial Development and Job Satisfaction: Basic results

\begin{tabular}{|c|c|c|c|c|c|c|c|}
\hline & $(1)$ & $(2)$ & $(3)$ & $(4)$ & $(5)$ & $(6)$ & $(7)$ \\
\hline $\mathrm{FD}^{*} \mathrm{SE}$ & & $\begin{array}{c}0.4932^{* * *} \\
(0.1074)\end{array}$ & $\begin{array}{c}0.3091^{* *} \\
(0.1390)\end{array}$ & $\begin{array}{c}0.4535^{* * *} \\
(0.1109)\end{array}$ & $\begin{array}{c}0.4391^{* * *} \\
(0.1310)\end{array}$ & $\begin{array}{c}0.3829 * * * \\
(0.1308)\end{array}$ & \\
\hline BANK*SE & & & & & & & $\begin{array}{c}0.0278^{* *} \\
(0.0141)\end{array}$ \\
\hline $\mathrm{GDP}^{*} \mathrm{SE}$ & & & $\begin{array}{c}0.0101^{* *} \\
(0.0047)\end{array}$ & & & & $\begin{array}{c}0.0103^{* * *} \\
(0.0035)\end{array}$ \\
\hline GROWTH*SE & & & & $\begin{array}{c}-0.0112 \\
(0.0082)\end{array}$ & & & \\
\hline UNEMP*SE & & & & & $\begin{array}{c}0.0048 \\
(0.0087)\end{array}$ & & \\
\hline REGULAT*SE & & & & & & $\begin{array}{c}0.0657 \\
(0.0402)\end{array}$ & \\
\hline $\mathrm{SE}$ & $\begin{array}{c}0.3679^{* * *} \\
(0.0478)\end{array}$ & $\begin{array}{c}0.0496 \\
(0.0910)\end{array}$ & $\begin{array}{c}0.0426 \\
(0.0916)\end{array}$ & $\begin{array}{c}0.1095 \\
(0.1015)\end{array}$ & $\begin{array}{c}0.0625 \\
(0.1519)\end{array}$ & $\begin{array}{l}-0.2306 \\
(0.1984)\end{array}$ & $\begin{array}{c}0.0823 \\
(0.0900)\end{array}$ \\
\hline Female & $\begin{array}{c}0.0004 \\
(0.0233)\end{array}$ & $\begin{array}{c}0.0028 \\
(0.0253)\end{array}$ & $\begin{array}{c}0.0077 \\
(0.0258)\end{array}$ & $\begin{array}{c}0.0057 \\
(0.0261)\end{array}$ & $\begin{array}{l}-0.0089 \\
(0.0295)\end{array}$ & $\begin{array}{c}0.0063 \\
(0.0253)\end{array}$ & $\begin{array}{c}0.0050 \\
(0.0250)\end{array}$ \\
\hline Age & $\begin{array}{c}0.0040 \\
(0.0043)\end{array}$ & $\begin{array}{c}0.0036 \\
(0.0045)\end{array}$ & $\begin{array}{c}0.0026 \\
(0.0044)\end{array}$ & $\begin{array}{c}0.0032 \\
(0.0044)\end{array}$ & $\begin{array}{c}0.0021 \\
(0.0063)\end{array}$ & $\begin{array}{c}0.0036 \\
(0.0046)\end{array}$ & $\begin{array}{c}0.0031 \\
(0.0043)\end{array}$ \\
\hline$(\text { Age })^{2}$ & $\begin{array}{c}0.0001^{* * *} \\
(0.0000)\end{array}$ & $\begin{array}{c}0.0001^{* * *} \\
(0.0000)\end{array}$ & $\begin{array}{c}0.0002^{* * *} * \\
(0.0000)\end{array}$ & $\begin{array}{c}0.0001^{* * *} \\
(0.0000)\end{array}$ & $\begin{array}{c}0.0002^{* *} \\
(0.0001)\end{array}$ & $\begin{array}{c}0.0001^{* * *} \\
(0.0001)\end{array}$ & $\begin{array}{c}0.0002^{* * *} * \\
(0.0000)\end{array}$ \\
\hline Married & $\begin{array}{c}0.1870^{* * *} \\
(0.0257)\end{array}$ & $\begin{array}{c}0.1904^{* * *} \\
(0.0281)\end{array}$ & $\begin{array}{c}0.1905^{* * *} \\
(0.0283)\end{array}$ & $\begin{array}{c}0.1905^{* * *} \\
(0.0285)\end{array}$ & $\begin{array}{c}0.1817^{* * *} \\
(0.0311)\end{array}$ & $\begin{array}{c}0.1884^{* * *} \\
(0.0285)\end{array}$ & $\begin{array}{c}0.1854^{* * *} \\
(0.0278)\end{array}$ \\
\hline Education & $\begin{array}{c}0.0305^{* * *} \\
(0.0067)\end{array}$ & $\begin{array}{c}0.0309 * * * \\
(0.0071)\end{array}$ & $\begin{array}{c}0.0312^{* * *} \\
(0.0072)\end{array}$ & $\begin{array}{c}0.0323^{* * *} * \\
(0.0073)\end{array}$ & $\begin{array}{c}0.0302^{* * *} \\
(0.0080)\end{array}$ & $\begin{array}{c}0.0306^{* * *} \\
(0.0073)\end{array}$ & $\begin{array}{c}0.0307^{* * *} \\
(0.0071)\end{array}$ \\
\hline Fixed Effects & YES & YES & YES & YES & YES & YES & YES \\
\hline "Observations & 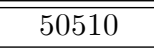 & 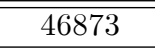 & 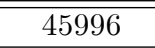 & 445550 & 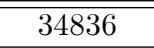 & 445855 & 446353 \\
\hline R-squared & 0.08 & 0.08 & 0.08 & 0.08 & 0.08 & 0.07 & 0.08 \\
\hline
\end{tabular}

Note: This table reports the results of OLS regressions with job satisfaction as dependent variable. All regressions include country-year dummies. The coefficient estimates and the standard errors for FD*SE are multiplied by 100 . The coefficient estimates and the standard errors for GDP*SE are multiplied by 1000. Robust standard errors, clustered at the country-employment status level, are in brackets. ${ }^{*},{ }^{* *}$ and ${ }^{* * *}$ denote rejection of the null hypothesis of the coefficient being equal to 0 at $10 \%, 5 \%$ and $1 \%$ significance level, respectively. 
Table 5: Financial Development and Job Satisfaction: Instrumental variables

\begin{tabular}{|c|c|c|c|c|c|c|}
\hline & $(1)$ & $(2)$ & $(3)$ & $(4)$ & $(5)$ & $(6)$ \\
\hline $\mathrm{FD}^{*} \mathrm{SE}$ & $\begin{array}{c}0.7497^{* *} \\
(0.3337)\end{array}$ & $\begin{array}{c}1.3359^{* * *} \\
(0.3188)\end{array}$ & $\begin{array}{c}1.3570 \\
(2.9899)\end{array}$ & $\begin{array}{c}0.9582^{* *} \\
(0.4369)\end{array}$ & $\begin{array}{c}1.0592^{* * *} \\
(0.2826)\end{array}$ & $\begin{array}{l}1.1922^{* *} \\
(0.4711)\end{array}$ \\
\hline SE & $\begin{array}{l}-0.1891 \\
(0.2287)\end{array}$ & $\begin{array}{c}-0.5752^{* *} \\
(0.2248)\end{array}$ & $\begin{array}{l}-0.6053 \\
(2.1437)\end{array}$ & $\begin{array}{c}-0.3232 \\
(0.3179)\end{array}$ & $\begin{array}{c}-0.3932^{* *} \\
(0.1969)\end{array}$ & $\begin{array}{l}-0.4887 \\
(0.3609)\end{array}$ \\
\hline Female & $\begin{array}{c}0.0044 \\
(0.0248)\end{array}$ & $\begin{array}{c}0.0091 \\
(0.0253)\end{array}$ & $\begin{array}{c}0.0116 \\
(0.0327)\end{array}$ & $\begin{array}{c}0.0107 \\
(0.0311)\end{array}$ & $\begin{array}{c}0.0093 \\
(0.0251)\end{array}$ & $\begin{array}{c}0.0112 \\
(0.0312)\end{array}$ \\
\hline Age & $\begin{array}{c}0.0026 \\
(0.0045)\end{array}$ & $\begin{array}{c}0.0031 \\
(0.0046)\end{array}$ & $\begin{array}{c}0.0086^{*} \\
(0.0052)\end{array}$ & $\begin{array}{l}0.0084^{*} \\
(0.0050)\end{array}$ & $\begin{array}{c}0.0030 \\
(0.0046)\end{array}$ & $\begin{array}{l}0.0085^{*} \\
(0.0050)\end{array}$ \\
\hline Age-sq & $\begin{array}{c}0.0001^{* * *} \\
(0.0000)\end{array}$ & $\begin{array}{c}0.0001^{* * *} \\
(0.0001)\end{array}$ & $\begin{array}{c}0.0001 \\
(0.0001)\end{array}$ & $\begin{array}{c}0.0001 \\
(0.0001)\end{array}$ & $\begin{array}{c}0.0001^{* * *} \\
(0.0001)\end{array}$ & $\begin{array}{c}0.0001 \\
(0.0001)\end{array}$ \\
\hline Married & $\begin{array}{c}0.1890^{* * *} \\
(0.0269)\end{array}$ & $\begin{array}{c}0.1855^{* * *} \\
(0.0276)\end{array}$ & $\begin{array}{c}0.2035^{* * * *} \\
(0.0336)\end{array}$ & $\begin{array}{c}0.2033^{* * *} \\
(0.0336)\end{array}$ & $\begin{array}{c}0.1856^{* * *} \\
(0.0276)\end{array}$ & $\begin{array}{c}0.2034^{* * *} \\
(0.0336)\end{array}$ \\
\hline Education & $\begin{array}{c}0.0348^{* * *} \\
(0.0073)\end{array}$ & $\begin{array}{c}0.0326^{* * *} \\
(0.0073)\end{array}$ & $\begin{array}{c}0.0253^{* * *} \\
(0.0089)\end{array}$ & $\begin{array}{c}0.0258^{* * *} \\
(0.0086)\end{array}$ & $\begin{array}{c}0.0328^{* * *} \\
(0.0073)\end{array}$ & $\begin{array}{c}0.0255^{* * *} \\
(0.0086)\end{array}$ \\
\hline Fixed Effects & YES & YES & YES & YES & YES & YES \\
\hline Instruments & TRUST & BANK & LEGAL & $\begin{array}{l}\text { LEGAL } \\
\text { TRUST }\end{array}$ & $\begin{array}{l}\text { BANK } \\
\text { TRUST }\end{array}$ & $\begin{array}{l}\text { LEGAL } \\
\text { BANK }\end{array}$ \\
\hline $\begin{array}{l}\text { F-stat } \\
\text { Hansen J-test }\end{array}$ & 11.85 & 8.98 & 0.12 & $\begin{array}{c}2.98 \\
0.8717\end{array}$ & $\begin{array}{c}6.17 \\
0.1347\end{array}$ & $\begin{array}{c}2.43 \\
0.9492\end{array}$ \\
\hline
\end{tabular}

\begin{tabular}{lcccccc}
\hline \hline Observations & 49101 & 47617 & 32566 & 32566 & 47617 & 32566 \\
\hline R-squared & 0.08 & 0.07 & 0.06 & 0.06 & 0.07 & 0.06 \\
\hline \hline
\end{tabular}

Note: This table reports the results of IV regressions with job satisfaction as dependent variable. All regressions include country-year dummies. The coefficient estimates and the standard errors for FD*SE are multiplied by 100 . The F-statistic refers to the null hypothesis that the coefficient of the excluded instrument is equal to zero in the first stage. Hansen J-test reports the p-values of Hansen overidentification test, under the null hypothesis that the instruments are valid. Robust standard errors, clustered at the country-employment status level, are in brackets. ${ }^{*},{ }^{* *}$ and ${ }^{* * *}$ denote rejection of the null hypothesis of the coefficient being equal to 0 at $10 \%, 5 \%$ and $1 \%$ significance level, respectively. 
Table 6: Financial Development and Job Satisfaction: Non-linear effects

\begin{tabular}{|c|c|c|c|c|c|c|c|}
\hline \multirow[b]{2}{*}{ Sample } & \multicolumn{2}{|c|}{ FD } & \multicolumn{2}{|c|}{ UNEMPL } & \multicolumn{2}{|c|}{ MINWAGE } & \multirow[b]{2}{*}{ Full } \\
\hline & Low & High & High & Low & High & Low & \\
\hline & $(1)$ & $(2)$ & $(3)$ & $(4)$ & $(5)$ & $(6)$ & $(7)$ \\
\hline $\mathrm{FD}^{*} \mathrm{SE}$ & $\begin{array}{c}0.8217^{* *} \\
(0.3476)\end{array}$ & $\begin{array}{c}0.0747 \\
(0.2238)\end{array}$ & $\begin{array}{c}0.5120^{* *} \\
(0.2546)\end{array}$ & $\begin{array}{c}0.1477 \\
(0.1779)\end{array}$ & $\begin{array}{c}0.6142^{* * *} \\
(0.1816)\end{array}$ & $\begin{array}{l}-0.3198 \\
(0.2054)\end{array}$ & $\begin{array}{c}2.4467^{* * *} \\
(0.8745)\end{array}$ \\
\hline $\mathrm{GDP}^{*} \mathrm{SE}$ & $\begin{array}{c}0.0120 \\
(0.0074)\end{array}$ & $\begin{array}{c}0.0063 \\
(0.0056)\end{array}$ & $\begin{array}{c}0.0052 \\
(0.0055)\end{array}$ & $\begin{array}{l}0.0129^{*} \\
(0.0067)\end{array}$ & $\begin{array}{c}0.0052 \\
(0.0079)\end{array}$ & $\begin{array}{l}-0.0076 \\
(0.0088)\end{array}$ & $\begin{array}{l}0.0084^{*} \\
(0.0047)\end{array}$ \\
\hline$\left(\mathrm{FD}^{*} \mathrm{SE}\right)^{2}$ & & & & & & & $\begin{array}{c}-2.5535^{* *} \\
(1.0127)\end{array}$ \\
\hline$\left(\mathrm{FD}^{*} \mathrm{SE}\right)^{3}$ & & & & & & & $\begin{array}{c}0.8337^{* *} \\
(0.3308)\end{array}$ \\
\hline $\mathrm{SE}$ & $\begin{array}{l}-0.1703 \\
(0.1370)\end{array}$ & $\begin{array}{c}0.3164 \\
(0.2067)\end{array}$ & $\begin{array}{c}-0.0362 \\
(0.1392)\end{array}$ & $\begin{array}{c}0.1401 \\
(0.1628)\end{array}$ & $\begin{array}{l}-0.1288 \\
(0.0867)\end{array}$ & $\begin{array}{c}0.9351^{* * *} \\
(0.2352)\end{array}$ & $\begin{array}{c}-0.3846^{*} \\
(0.2025)\end{array}$ \\
\hline Female & $\begin{array}{c}0.0262 \\
(0.0389)\end{array}$ & $\begin{array}{l}-0.0126 \\
(0.0293)\end{array}$ & $\begin{array}{c}0.0030 \\
(0.0360)\end{array}$ & $\begin{array}{c}0.0140 \\
(0.0352)\end{array}$ & $\begin{array}{c}0.0063 \\
(0.0376)\end{array}$ & $\begin{array}{c}-0.0071 \\
(0.0442)\end{array}$ & $\begin{array}{c}0.0072 \\
(0.0260)\end{array}$ \\
\hline Age & $\begin{array}{c}0.0080 \\
(0.0072)\end{array}$ & $\begin{array}{l}-0.0026 \\
(0.0061)\end{array}$ & $\begin{array}{l}-0.0003 \\
(0.0055)\end{array}$ & $\begin{array}{c}0.0064 \\
(0.0085)\end{array}$ & $\begin{array}{c}0.0000 \\
(0.0061)\end{array}$ & $\begin{array}{c}0.0042 \\
(0.0075)\end{array}$ & $\begin{array}{c}0.0025 \\
(0.0044)\end{array}$ \\
\hline Age-sq & $\begin{array}{c}0.0001 \\
(0.0001)\end{array}$ & $\begin{array}{c}0.0002^{* * *} \\
(0.0001)\end{array}$ & $\begin{array}{c}0.0002^{* * *} \\
(0.0001)\end{array}$ & $\begin{array}{c}0.0001 \\
(0.0001)\end{array}$ & $\begin{array}{c}0.2342^{* * *} \\
(0.0408)\end{array}$ & $\begin{array}{c}0.1243^{* * *} \\
(0.0339)\end{array}$ & $\begin{array}{c}0.0002^{* * *} \\
(0.0000)\end{array}$ \\
\hline Married & $\begin{array}{c}0.1951^{* * *} \\
(0.0383)\end{array}$ & $\begin{array}{c}0.1848^{* * *} \\
(0.0371)\end{array}$ & $\begin{array}{c}0.2255^{* * *} \\
(0.0370)\end{array}$ & $\begin{array}{c}0.1332^{* * *} \\
(0.0404)\end{array}$ & $\begin{array}{c}0.0002^{* *} \\
(0.0001)\end{array}$ & $\begin{array}{l}0.0002 * \\
(0.0001)\end{array}$ & $\begin{array}{c}0.1902^{* * *} \\
(0.0283)\end{array}$ \\
\hline Education & $\begin{array}{c}0.0392^{* * *} \\
(0.0106)\end{array}$ & $\begin{array}{c}0.0238^{* *} \\
(0.0104)\end{array}$ & $\begin{array}{c}0.0474^{* * *} \\
(0.0095)\end{array}$ & $\begin{array}{c}0.0048 \\
(0.0076)\end{array}$ & $\begin{array}{c}0.0369^{* * *} \\
(0.0099)\end{array}$ & $\begin{array}{c}0.0204 \\
(0.0121)\end{array}$ & $\begin{array}{c}0.0313^{* * *} \\
(0.0072)\end{array}$ \\
\hline Fixed Effects & YES & YES & YES & YES & YES & YES & YES \\
\hline Observations & 23359 & 22637 & 28737 & 17259 & 26182 & 14756 & 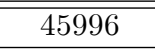 \\
\hline R-squared & 0.09 & 0.07 & 0.08 & 0.07 & 0.06 & 0.06 & 0.08 \\
\hline
\end{tabular}

Note: This table reports the results of OLS regressions with job satisfaction as dependent variable. All regressions include country-year dummies. In columns (1)-(2), Low FD and High FD indicate that the sample is restricted to countries respectively below and above the median value of FD in our sample (equal to 71.78). Similarly, in columns (3)-(4), High UNEMPL and Low UNEMPL indicate that the sample is restricted to countries respectively above and below the median value of UNEMPL in our sample (equal to 8.2); and in columns (5)-(6), High MINWAGE and Low MINWAGE indicate that the sample is restricted to countries respectively with and without a mandatory minimum wage. The coefficient estimates and the standard errors for FD*SE are multiplied by 100 . The coefficient estimates and the standard errors for GDP*SE are multiplied by 1000. Robust standard errors, clustered at the country-employment status level, are in brackets. ${ }^{*},{ }^{* *}$ and ${ }^{* * *}$ denote rejection of the null hypothesis of the coefficient being equal to 0 at $10 \%, 5 \%$ and $1 \%$ significance level, respectively. 
Table 7: Financial Development and Job Satisfaction: Mechanisms

\begin{tabular}{|c|c|c|c|c|c|c|}
\hline Sample & $\begin{array}{c}\text { Full } \\
(1) \\
\end{array}$ & $\begin{array}{c}\text { Low FD } \\
(2)\end{array}$ & $\begin{array}{c}\text { High FD } \\
(3) \\
\end{array}$ & $\begin{array}{c}\text { Full } \\
(4)\end{array}$ & $\begin{array}{c}\text { Low FD } \\
(5)\end{array}$ & $\begin{array}{c}\text { High FD } \\
(6)\end{array}$ \\
\hline $\mathrm{FD}^{*} \mathrm{SE}$ & & $\begin{array}{c}0.9113^{* *} \\
(0.3576)\end{array}$ & $\begin{array}{l}-0.0249 \\
(0.2366)\end{array}$ & & $\begin{array}{c}0.4510 \\
(0.3431)\end{array}$ & $\begin{array}{c}0.1818 \\
(0.2117)\end{array}$ \\
\hline $\mathrm{GDP}^{*} \mathrm{SE}$ & & $\begin{array}{l}0.0153^{*} \\
(0.0079)\end{array}$ & $\begin{array}{c}0.0090 \\
(0.0058)\end{array}$ & & $\begin{array}{c}0.0136 \\
(0.0087)\end{array}$ & $\begin{array}{c}0.0124^{* * *} \\
(0.0045)\end{array}$ \\
\hline Income & $\begin{array}{c}0.1037^{* * *} \\
(0.0097)\end{array}$ & $\begin{array}{c}0.1142^{* * *} \\
(0.0135)\end{array}$ & $\begin{array}{c}0.0944^{* * *} \\
(0.0145)\end{array}$ & & & \\
\hline Independence & & & & $\begin{array}{c}0.3418^{* * *} \\
(0.0089)\end{array}$ & $\begin{array}{c}0.3287^{* * *} \\
(0.0123)\end{array}$ & $\begin{array}{c}0.3513^{* * *} \\
(0.0124)\end{array}$ \\
\hline SE & $\begin{array}{c}0.3259^{* * *} \\
(0.0506)\end{array}$ & $\begin{array}{c}-0.2866^{* *} \\
(0.1347)\end{array}$ & $\begin{array}{l}0.3645^{*} \\
(0.1858)\end{array}$ & $\begin{array}{c}-0.3372^{* * *} \\
(0.0471)\end{array}$ & $\begin{array}{c}-0.7240^{* * *} \\
(0.1442)\end{array}$ & $\begin{array}{r}-0.6136^{* * *} \\
(0.1873)\end{array}$ \\
\hline Female & $\begin{array}{c}0.0001 \\
(0.0250)\end{array}$ & $\begin{array}{c}0.0325 \\
(0.0433)\end{array}$ & $\begin{array}{c}-0.0170 \\
(0.0292)\end{array}$ & $\begin{array}{c}0.1067^{* * *} * \\
(0.0216)\end{array}$ & $\begin{array}{c}0.1444^{* * *} \\
(0.0336)\end{array}$ & $\begin{array}{c}0.0772^{* *} \\
(0.0308)\end{array}$ \\
\hline Age & $\begin{array}{c}0.0031 \\
(0.0045)\end{array}$ & $\begin{array}{c}0.0056 \\
(0.0082)\end{array}$ & $\begin{array}{l}-0.0037 \\
(0.0061)\end{array}$ & $\begin{array}{c}-0.0181^{* * *} \\
(0.0042)\end{array}$ & $\begin{array}{c}-0.0155^{* *} \\
(0.0062)\end{array}$ & $\begin{array}{c}-0.0241^{* * *} \\
(0.0067)\end{array}$ \\
\hline$(\text { Age })^{2}$ & $\begin{array}{c}0.0002^{* * *} \\
(0.0001)\end{array}$ & $\begin{array}{c}0.0001 \\
(0.0001)\end{array}$ & $\begin{array}{c}0.0002^{* * *} \\
(0.0001)\end{array}$ & $\begin{array}{c}0.0003^{* * *} \\
(0.0000)\end{array}$ & $\begin{array}{c}0.0003^{* * *} \\
(0.0001)\end{array}$ & $\begin{array}{c}0.0004^{* * *} \\
(0.0001)\end{array}$ \\
\hline Married & $\begin{array}{c}0.1111^{* * *} \\
(0.0292)\end{array}$ & $\begin{array}{c}0.1175^{* *} \\
(0.0454)\end{array}$ & $\begin{array}{c}0.1012^{* *} \\
(0.0414)\end{array}$ & $\begin{array}{c}0.1186^{* * *} \\
(0.0239)\end{array}$ & $\begin{array}{c}0.1409 * * * \\
(0.0331)\end{array}$ & $\begin{array}{c}0.1070^{* * *} \\
(0.0360)\end{array}$ \\
\hline Education & $\begin{array}{l}0.0114^{*} \\
(0.0058)\end{array}$ & $\begin{array}{l}0.0198^{*} \\
(0.0099)\end{array}$ & $\begin{array}{c}0.0036 \\
(0.0083)\end{array}$ & $\begin{array}{c}-0.0197^{* * *} \\
(0.0055)\end{array}$ & $\begin{array}{c}-0.0179^{* *} \\
(0.0087)\end{array}$ & $\begin{array}{c}-0.0181^{* *} \\
(0.0079)\end{array}$ \\
\hline Fixed Effects & YES & YES & YES & YES & YES & YES \\
\hline "Observations & 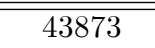 & 20526 & 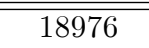 & $\overline{50049}$ & 23107 & 222519 \\
\hline R-squared & 0.09 & 0.10 & 0.08 & 0.23 & 0.23 & 0.24 \\
\hline
\end{tabular}

Note: This table reports the results of OLS regressions with job satisfaction as dependent variable. All regressions include country-year dummies. Low FD and High FD indicate that the sample is restricted to countries respectively below and above the median value of FD in our sample (equal to 71.78). The coefficient estimates and the standard errors for FD*SE are multiplied by 100 . The coefficient estimates and the standard errors for GDP*SE are multiplied by 1000 . Robust standard errors, clustered at the country-employment status level, are in brackets. ${ }^{*},{ }^{* *}$ and ${ }^{* * *}$ denote rejection of the null hypothesis of the coefficient being equal to 0 at $10 \%, 5 \%$ and $1 \%$ significance level, respectively. 
Table 8: Financial Development and Income

\begin{tabular}{|c|c|c|c|c|c|}
\hline Sample & $\begin{array}{c}\text { Low FD } \\
\text { (1) }\end{array}$ & $\begin{array}{l}\text { High FD } \\
(2)\end{array}$ & $\begin{array}{c}\text { Full } \\
(3)\end{array}$ & $\begin{array}{c}\text { Low FD } \\
(4)\end{array}$ & $\begin{array}{c}\text { High FD } \\
(5)\end{array}$ \\
\hline $\mathrm{FD}^{*} \mathrm{SE}$ & & & $\begin{array}{c}-0.4107^{* *} \\
(0.1956)\end{array}$ & $\begin{array}{c}-1.3760^{* * *} \\
(0.3989)\end{array}$ & $\begin{array}{l}-0.0027 \\
(0.4473)\end{array}$ \\
\hline $\mathrm{GDP}^{*} \mathrm{SE}$ & & & $\begin{array}{c}0.0027 \\
(0.0059)\end{array}$ & $\begin{array}{c}0.0087 \\
(0.0084)\end{array}$ & $\begin{array}{c}0.0022 \\
(0.0094)\end{array}$ \\
\hline $\mathrm{SE}$ & $\begin{array}{c}0.2935^{* * *} \\
(0.0728)\end{array}$ & $\begin{array}{c}0.1183 \\
(0.0823)\end{array}$ & $\begin{array}{c}0.4228^{* * *} \\
(0.1082)\end{array}$ & $\begin{array}{c}0.7426^{* * *} \\
(0.1273)\end{array}$ & $\begin{array}{c}0.0473 \\
(0.3842)\end{array}$ \\
\hline Female & $\begin{array}{c}-0.1175^{* * *} \\
(0.0360)\end{array}$ & $\begin{array}{c}-0.0391 \\
(0.0567)\end{array}$ & $\begin{array}{l}-0.0625 \\
(0.0395)\end{array}$ & $\begin{array}{c}-0.1222^{* * *} \\
(0.0369)\end{array}$ & $\begin{array}{c}0.0063 \\
(0.0642)\end{array}$ \\
\hline Age & $\begin{array}{c}-0.0042 \\
(0.0161)\end{array}$ & $\begin{array}{c}0.0094 \\
(0.0164)\end{array}$ & $\begin{array}{c}0.0071 \\
(0.0139)\end{array}$ & $\begin{array}{c}-0.0046 \\
(0.0163)\end{array}$ & $\begin{array}{c}0.0202 \\
(0.0193)\end{array}$ \\
\hline$(\text { Age })^{2}$ & $\begin{array}{c}0.0000 \\
(0.0002)\end{array}$ & $\begin{array}{l}-0.0000 \\
(0.0002)\end{array}$ & $\begin{array}{l}-0.0001 \\
(0.0002)\end{array}$ & $\begin{array}{c}0.0000 \\
(0.0002)\end{array}$ & $\begin{array}{l}-0.0002 \\
(0.0002)\end{array}$ \\
\hline Married & $\begin{array}{c}0.7280^{* * *} \\
(0.1318)\end{array}$ & $\begin{array}{c}0.9110^{* * *} \\
(0.1231)\end{array}$ & $\begin{array}{c}0.8770^{* * *} \\
(0.0960)\end{array}$ & $\begin{array}{c}0.7369^{* * *} \\
(0.1312)\end{array}$ & $\begin{array}{c}1.0272^{* * *} \\
(0.1270)\end{array}$ \\
\hline Education & $\begin{array}{c}0.2202^{* * *} \\
(0.0136)\end{array}$ & $\begin{array}{c}0.2172^{* * *} \\
(0.0185)\end{array}$ & $\begin{array}{c}0.2289^{* * *} \\
(0.0110)\end{array}$ & $\begin{array}{c}0.2214^{* * *} \\
(0.0137)\end{array}$ & $\begin{array}{c}0.2373^{* * *} \\
(0.0199)\end{array}$ \\
\hline Fixed Effects & YES & YES & YES & YES & YES \\
\hline Observations & 20976 & 22897 & 39502 & 20526 & 18976 \\
\hline R-squared & 0.35 & 0.31 & 0.32 & 0.35 & 0.29 \\
\hline
\end{tabular}

Note: This table reports the results of OLS regressions with income as dependent variable. All regressions include country-year dummies. Low FD and High FD indicate that the sample is restricted to countries respectively below and above the median value of FD in our sample (equal to 71.78). The coefficient estimates and the standard errors for FD*SE are multiplied by 100 . The coefficient estimates and the standard errors for GDP*SE are multiplied by 1000 . Robust standard errors, clustered at the country-employment status level, are in brackets. ${ }^{*},{ }^{* *}$ and ${ }^{* * *}$ denote rejection of the null hypothesis of the coefficient being equal to 0 at $10 \%, 5 \%$ and $1 \%$ significance level, respectively. 